\title{
Introduction, Recovery, and Limited Establishment of Coleophora klimeschiella (Lepidoptera: Coleophoridae) on Russian Thistles, Salsola australis, in Southern California
}

\author{
R. D. GOEDEN, D. W. RICKER, AND H. MÜLLER' \\ Division of Biological Control, Department of Entomology, \\ University of California, Riverside, California 92521
}

\begin{abstract}
Environ. Entomol. 16: 1027-1029 (1987)
ABSTRACT Although case-bearing leafmining larvae of Coleophora klimeschiella Toll were released on Russian thistles, Salsola australis R. Brown (Chenopodiaceae), at 13 locations in southern California during 1977-85, this biological control agent remained tenuously established at only one site by late 1986. Neither insectary-reared or field-collected stocks released in field cages or in the open in numbers of 100-600 per site appeared to foster colony establishment. Poor host-plant adaptation as well as predation and parasitism by indigenous natural enemies are identified as possible sources of biotic resistance to the establishment of this imported insect. The predator, Phylobacnus atriplexus (Foster) (Coleoptera: Cleridae), and the primary parasite, Macroneura sp. (Hymenoptera: Eupelmidae), found attacking C. klimeschiella, also are known from gall-midge hosts on native saltbushes (Atriplex spp., also Chenopodiaceae).
\end{abstract}

KEY WORDS Salsola, Coleophora, biological control, colonization, natural enemies

Coleophora klimeschiella Toll (Lepidoptera: Coleophoridae) is the second species of phytophagous insect, besides C. parthenica Meyrick, to be introduced into the western United States from Pakistan by ARS-USDA entomologists for the biological control of the Russian thistle, Salsola australis R. Brown (Chenopodiaceae) (Hawkes et al. 1975, Julien 1982). The biology and host specificity of this case-bearing leaf miner was described by Khan \& Baloch (1976) and Hawkes \& Mayfield (1978), respectively. This report describes our experience with C. Klimeschiella in southern California since 1977, including where and when it first was introduced by us as collaborators, while others handled introductions in central and northern California (Hawkes 1978, Julien 1982).

\section{Materials and Methods}

Insectary Culture. Sixty-four late instars and pupae of C. klimeschiella were received at Riverside from the ARS-USDA Biological Control of Weeds Laboratory, Albany, Calif,, on 14 April 1977. These specimens were collected from a culture maintained at Albany that originated from material collected in Pakistan on Salsola ruthenica Iljin (Khan \& Baloch 1976, Hawkes \& Mayfield 1978). Upon receipt, these larvae and pupae were caged in the insectary of the Division of Biological Control on vegetative Salsola australis greenhouse-grown from transplanted, field-collected seedlings. Glass-topped

' Current address: Zoologiches Institut der Universität Basel, theinsprung 9, CH-4051 Basel, Switzerland. sleeve cages ( 34 by 32 by $35 \mathrm{~cm}$ ), each containing a single potted plant as described by Gilstrap \& Goeden (1974), were used exclusively for insectary rearings at $26 \pm 1^{\circ} \mathrm{C}$ and a $15: 9(\mathrm{~L}: \mathrm{D})$ photoperiod during 1977 and 1978.

Approximately half-grown fourth instars were transferred to fresh plants individually, with forceps, by pinching off the leaves with the larvae attached whenever their feeding damage on plants became severe. New cagings were initiated with eggs oviposited by insectary-reared moths. In November 1977, insectary-cultured, fully grown larvae and pupae were stored for the winter in a cold room in darkness at $2^{\circ} \mathrm{C}$ while attached within their tubular cases to branches of basally excised plants. Each infested plant was individually placed in a large paper bag that was taped shut basally and hung from a wall hook. Moths emerging from some of these overwintered individuals were used to restart insectary cultures in April 1978, and these cultures were maintained as described above until August 1978. An additional 150 larvae, reared from material collected in Pakistan in the fall of 1977, were received from the Albany laboratory on 17 May 1978 and added to stock already in culture at Riverside. A total of 98 potted plants was caged with adults or half-grown larvae in 1977; 120 plants were similarly caged in 1978 . These rearings yielded the 918 larvae or pupae and 13 adults released in southern California in 1977, and the 600 larvae or pupae released in 1978 (Table 1).

Colonizations. Table 1 lists release data for $C$. klimeschiella at 13 locations in southern California. Thirteen moths reared from the initial shipment from Albany were introduced into field cages cov- 
ered with fine-mesh fiberglass window screen (1.2 by 1.8 by $0.5 \mathrm{~m}$ ) previously positioned over vigorous, young Russian thistles at the University of California Moreno Valley Field Station. Last instars and pupae were subsequently also introduced into this field cage and a second field cage, respectively (Table 1). The cages were removed in July 1977 when the actively growing thistles occupied about half of the interior of the cages. Subsequent releases during 1977 and 1978 involved transporting insectary-reared larvae or pupae to preselected sites in ice-cream cartons filled with loosely bunched paper toweling within cold chests in an air-conditioned vehicle. Toweling and open cartons were carefully tucked into the crowns of vigorous Russian thistles into which the larvae readily moved.

The larvae or pupae released at the east and west Indio sites in 1983 and 1984 (Table 1), were obtained from a single large plant bearing most of the larval survivors of a 4 -yr-old colony tenuously established at east Indio site 1. The latter site had been colonized by the direct release of larvae and moths received from Albany on 25 June 1979 (Table 1).

All the insects for the 1985 releases were obtained from a colony of C. klimeschiella established since 1977 by ARS-USDA entomologists at Coalinga, Fresno County, in the San Joaquin Valley in central California. Nine early-fruiting-stage plants with dense blue-green leaves that bore most of the current-generation larvae (darker and grayish versus whitish to light tan empty larval cases) at this site were measured and then cut off basally at the central, main stem just above the ground. The intact infested shoots were transported by an air-conditioned vehicle to Riverside and stored at $2^{\circ} \mathrm{C}$. The cases were placed at room temperature in closed ice-cream cartons containing paper toweling upon which the active larvae climbed. The larval cases that remained on the container floors were examined after a few days for parasite exit holes, and those found to be intact but not empty were held for possible parasite emergence in individual gelatin capsules in the insectary. The 3,650 active, field-collected larvae or newly formed pupae were liberated by inserting the toweling and open cartons in crowns of vigorous Russian thistles at five locations in Riverside County through 22 October 1985 (Table 1).

Recovery. Recovery efforts at each release site consisted of careful examination of plants, mainly for larval cases, but also for adults. Visits were made as time permited, but rarely at intervals $<1 \mathrm{mo}$ during 1977-86.

\section{Results and Discussion}

As of September 1986, C. klimeschiella larvae continued to be recovered in small numbers only at our Riverside colonization site (Table 1). This meant that colonies started within field cages or in the open, with insectary reared or field-collected
Table 1. Release data for $C$. klimeschiella in southern California

\begin{tabular}{|c|c|c|c|c|}
\hline \multicolumn{2}{|c|}{ Release } & \multicolumn{2}{|c|}{ No. released } & \multirow{2}{*}{$\begin{array}{l}\text { Colony } \\
\text { estab- } \\
\text { lished? }\end{array}$} \\
\hline Site & Date(s) & $\begin{array}{c}\text { Larvae/ } \\
\text { pupae }\end{array}$ & Adults & \\
\hline \multirow[t]{3}{*}{ Moreno } & 26 Apr. 1977 & & 13 & \\
\hline & 31 May 1977 & 22 & & \\
\hline & 21 June 1977 & 100 & & No \\
\hline Lake Perris & 8 July 1977 & 100 & & No \\
\hline Bonsall & 15 Aug. 1977 & 110 & & No \\
\hline \multirow{2}{*}{ Ramona } & 15 Aug. 1977 & 177 & & \\
\hline & 22 Sept. 1977 & 142 & & No \\
\hline \multirow[t]{2}{*}{ Del Mar } & 22 Sept. 1977 & 267 & & \\
\hline & 24 Aug. 1978 & 600 & & No \\
\hline E. Indio no. 1 & 25 June 1979 & 278 & 2 & $\mathrm{No}^{a}$ \\
\hline E. Indio no. 2 & 15 Nov. 1983 & $684^{b}$ & & No \\
\hline W. Indio no. 1 . & 29 Mar. 1984 & $1,650^{\prime \prime}$ & & No \\
\hline \multirow[t]{2}{*}{ Highgrove } & 2 Oct. 1985 & 400 & & \\
\hline & 21 Oct. 1985 & 400 & & No \\
\hline \multirow[t]{2}{*}{ E. Indio no. 3} & 17 Oct. 1985 & 600 & & \\
\hline & 6 Noy. 1985 & 250 & & No \\
\hline W. Indio no. 2 & 17 Oct. 1985 & 600 & & No \\
\hline Banning & 17 Oct. 1985 & 600 & & No \\
\hline Riverside & 22 Oct. 1985 & 800 & & $?$ \\
\hline Total & & 7,780 & & \\
\hline
\end{tabular}

${ }^{a}$ Colony survived at low densities from 1979 to 1983 . See text.

${ }^{b}$ Apparently heavily parasitized. See text.

larvae or pupae, and with as many as 600 unparasitized, insectary individuals, i.e., Del Mar in 1978, failed to become established. This poor performance partly may be the result of poor adaptation of this insect to $S$. australis, because it originated on another host-plant species, $S$. ruthenica, in $\mathrm{Pa}-$ kistan (Khan \& Baloch 1976, Hokkanen \& Pimentel 1984, Goeden \& Kok 1986). Field observations during four consecutive years at Indio site 1 indicated that $<10 \%$ of the plants were infested by C. klimeschiella at prevailing generally low population densities. Moreover, this colony never spread more than $200 \mathrm{~m}$ from the colonization point during the $4 \mathrm{yr}$ of its tenuous existence, again indicative of a poor adaptation of this moth to Russian thistle.

A single plant bearing 2,453 larval cases at Indio site 1 provided material for releases in east and west Indio in late 1983 and early 1984, respectively. However, this field-collected material apparently was heavily parasitized. A sample of 10 branches representing about $1 \%$ of the crown of this plant bore a total of 121 larval cases, of which $17(14 \%)$ showed lateral exit holes of parasites and 19 (16\%) contained active C. klimeschiella larvae. The remaining 85 cases held in individual gelatin capsules yielded $7(6 \%)$ moths, $4(3 \%)$ Phyllobaenus atriplexus (Foster) (Coleoptera: Cleridae, a predator), and the following hymenopterous parasites: 30 (25\%) Macroneura sp. (Eupelmidae), 20 (17\%) Hockeria sp. (Chalcididae), 5 (4\%) Catolaccus aeneoviridis (Girault) (Pteromalidae, probably a hyperparasite), 3 (2\%) Cerambycobrius sp. (Eupelmidae), and 2 ( $1 \%$ ) unidentified Ichneumonidae). Fourteen (12\%) cases contained larvae that died from unknown causes. This suggests a parasitization and predation rate of at least $66 \%$ in over- 
wintering C. klimeschiella and another apparent reason for the poor performance of this biological control agent in southern California. Hawkins \& Goeden (1984) reported $P$. atriplexus and the same Macroneura sp. as natural enemies of native Cecidomyiidae forming galls on the salt bushes, Atriplex canescens (Pursh) Nuttall and Atriplex polycarpa (Torrey) Watson (Chenopodiaceae). These galled halophytes are common associates of Russian thistle in southern California (Hawkins et al. 1986). This documented source of biotic resistance to the colonization of C. klimeschiella provides another example of a phenomenon reviewed by Goeden \& Louda (1976) for other species of phytophagous insects imported for biological control of weeds.

We have no further plans to introduce C. klimeschiella in southern California, and conclude from our efforts to date that this species is an ineffective biological control agent.

\section{Acknowledgment}

Our sincere thanks to the Biological Control of Weeds Laboratory (ARS-USDA, Albany, Calif.) for supplying C. klimeschiella. We also thank the following taxonomists for identifications of adopted natural enemies of C. klimeschiella: W. F. Barr (Department of Entomology, University of Idaho, Moscow); G. Gibson (Department of Entomology, University of Alberta, Edmonton); and E. E. Grissell (Systematic Entomology Laboratory, ARS-USDA, Beltsville, Md.). J. A. McMurtry and E. R. Oatman provided helpful comments on a draft of the manuscript.

\section{References Cited}

Gilstrap, F. E. \& R. D. Goeden. 1974. Biology of Tarachidia candefacta, a Nearctic noctuid intro- duced into the U.S.S.R. for ragweed control. Ann. Entomol. Soc. Am. 67: 265-270.

Goeden, R. D. \& L. T. Kok. 1986. Comments on a proposed "new" approach for selecting agents for the biological control of weeds. Can. Entomol. 118: 5158.

Goeden, R. D. \& S. Louda. 1976. Biotic interference with insects imported for weed control. Annu. Rev. Entomol. 21: 325-342.

Hawkes, R. B. 1978. Biological control of Russian thistle along California highways. Calif. Dep. Transp. Publ. T 900 B55.

Hawkes, R. B. \& A. Mayfield. 1978. Coleophora klimeschiella, biological control agent for Russian thistle: host specificity testing. Environ. Entomol. 7: 257-271.

Hawkes, R. B., R. D. Goeden, A. Mayfield \& D. W. Ricker. 1975. Biological control of Russian thistle. Calif. Agric. 29(4): 3-4.

Hawkins, B. A. \& R. D. Goeden. 1984. Organization of a parasitoid community associated with a complex of galls on Atriplex spp. in southern California. Ecol. Entomol. 9: 271-292.

Hawkins, B. A., R. D. Goeden \& R. L. Gagné. 1986. Ecology and taxonomy of the Asphondylia spp. (Diptera: Cecidomyiidae) forming galls on Atriplex spp. (Chenopodiaceae) in southern California. Entomography 4: 55-107.

Hokkanen, H. \& D. Pimentel. 1984. New approach for selecting biological control agents. Can. Entomol. 116: 1109-1121.

Julien, M. H. 1982. Biological control of weeds: a world catalogue of agents and their target weeds. Unwin, Surrey, England

Khan, A. G. \& G. M. Baloch. 1976. Coleophora klimeschiella (Lep.: Coleophoridae), a promising biocontrol agent for Russian thistles, Salsola spp. Entomophaga 21: 425-428.

Received for publication 19 November 1986; accepted 24 April 1987. 